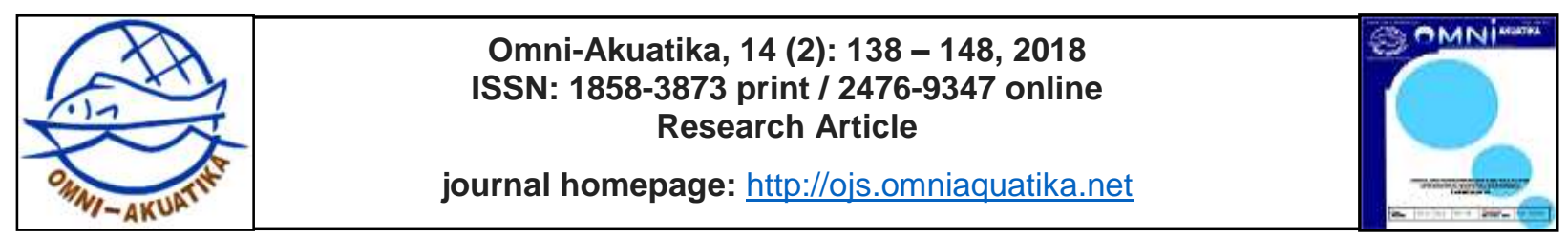

\title{
Engineering Technology of White Shrimp (Litopenaeus vannamei) Intensive System Culture with the Suplementation of Phytase Enzyme in the Diet
}

\author{
Diana Rachmawati ${ }^{{ }^{*}}$, Istiyanto Samidjan ${ }^{1}$ \\ ${ }^{1}$ Aquaculture Department of Fisheries, Faculty of Fisheries and Marine Sciences, Diponegoro University, \\ Jl. Prof. Soedarto, SH, Tembalang, Semarang, 50275 Indonesia
}

${ }^{*}$ Corresponding author: dianarachmawati1964@gmail.com

\begin{abstract}
This study aims to examine the effect of phytase enzyme in the diet on digestibility of growth of white shrimp (Litopenaeus vannamei) raised in intensive system culture. Research on the suplementation of phytase enzymes in L. vannamei diet is very important to hydrolyze phytic acid in vegetable ingredients as a source of diet protein so as to increase the efficiency of diet utilization to support growth of vaname shrimp. The shrimp used in the research had average weight of $1,19 \pm 0,06$ $\mathrm{g} / \mathrm{shrimp}$. The diet contained $38 \%$ of protein and $3200 \mathrm{Kcal} \mathrm{DE} / \mathrm{kg}$ with various doses of phytase enzyme suplementation, namely: A (0 U/kg diet), B (500 U/kg diet), C (1000 U/kg diet) and D (1500 $\mathrm{U} / \mathrm{kg}$ diet). Observed parameters were digestibility of phosphore $\left(A D C_{F}\right)$, disgetibility of protein $\left(A D C_{P}\right)$, efficiency of diet utilitzation (EFU), protein efficiency ratio (PER), diet convesion ratio (FCR) relative growth rate (RGR), and survival rate (SR). The suplementation of phytase enzyme in the diet significantly influenced $(P<0.01)$ on $A D C_{F}, A D C_{P}, E F U, P E R, F C R, R G R$; however, it did not significantly influence on SR of white shrimp. The best treatment result was the suplementation of $1000 \mathrm{U} / \mathrm{kg}$ diet phytase enzyme (treatment C). The optimum dose of phytase enzyme in the diet was 867, 920, 923, 915, 1000 and $1000 \mathrm{U} / \mathrm{kg}$ of diet respectively for ADCF, ADCP, EFU, PER, FCR, RGR. Based on those result the suplementation of phytase enzyme can increase the growth of white shrimp.
\end{abstract}

Keywords: growth, intensive system culture, Suplementation, phytase enzyme

\section{Introduction}

White shrimp (Litopenaeus vannamei) is one of the aquaculture products Kendal District, Province of Central Java, Indonesia. The district has potential area for aquaculture with the area of $1.000 .23 \mathrm{~km} 2$ and sea shore line of $42.2 \mathrm{~km}$. The aquaculture system on white shrimp in the Kendal District has not been optimum yet. One of the reasons is high price of the diet, but it is not followed by the price of the shrimp. Moreover, the share of production cost dominated total cost, it counted for 50 $60 \%$, where the contribution of frozen $L$. vannamei export value to the total value of 2016 fishery exports is more than 27\% (Office of Fishery and Maritime District of Kendal, 2018). The success of white shrimp aquaculture highly depends on the efficiency of diet utlization because it can reduce cost of production. Efficiency of diet utlization has not been optimum yet due to the diet that made of plant based ingredients.

Kumar et al. (2011) reported that the main problem of plant based diet is because it contains phytic acid. Soybean meal of $1 \mathrm{~kg}$ contains $3.88 \mathrm{~g}$ (Cao et al., 2007). Minerals that have 2 or 3 valences $(\mathrm{Ca}, \mathrm{Fe}, \mathrm{Zn}, \mathrm{Mg})$ can be bound by phytic acid. Then it creates complex compound that highly difficult to absorb (Baruah et al., 2007). Phytic acid can also bind protein and amino acids that can hinder diet digestibility (Ravindran et al., 2005). mineral yang memiliki 2 atau 3 valensi ( $\mathrm{Ca}, \mathrm{Fe}, \mathrm{Zn}, \mathrm{Mg}$ ) dapat diikat oleh asam fitat.

Phosphore is one of macro nutrients that fish needs to grow (Jagannathan and Nielsen, 2013). Fish cannot utilize phosphore in the diet made of plant based ingredients, because fish has limited phytase enzyme (Debnath et al., 2005). About $80 \%$ of the total phosphorus 
available in the plant-based diet is bound by phytic acid (Kumar et al., 2011). Therefore, fish cannot directly absorb the binded phosphore in the phytic acid, in turn it is excreted thwough feces. Accumulated feces will release phosphore and will put more nutrient in the aquaculture media. High phoshore content in the water can cause eutrophycation that will harm the fish culture (Baruah et al., 2007).

One way to overcome the problem of phytic acid. with phytase enzyme supplementation in feed (Kumar et al., 2011), the addition of phytase enzymes in feed can be one way to overcome the problem of phytic acid. Phytase enzyme hydrolizes phytic acid; therefore, it will unbind minerals from the compound (Chung, 2001). The enzyme phytase is an enzyme that can hydrolyze phytic acid so can increase absorption of nutrients and minerals (Baruah et al., 2007). It can also hrdrolize phytic acid into inositol and phosphate acid. Beside unbinding phosphore from phytic acid, phytase enzyme can also unbind other minerals (Ravindran et al., 2005). Some studies on phytase enzyme suplementation in the diet have been done by Shapawi et al., (2013), Hassan et al. (2009), Husain et al. (2014), Bulbul et al. (2015), Danwitz et al. (2016).

There is no information found in the study of phytase enzyme supplementation in the diet or the growth of $L$. vannamei so this study is indispensable. This study aims to examine the effect of phytase enzyme in the diet on digestibility of growth of white shrimp (Litopenaeus vannamei) raised in intensive system culture.

\section{Materials and methods}

\section{Shrimp Sample}

White shrimp (L. vannamei) used in the study has average weight of $1.19 \pm 0.06$ g/shrimp. The shrimp was obtained from Brackish Water Aquaculture Center, Situbondo, East Java, Indonesia. The sample shrimp was selected based on the size uniformity, organ completeness, and health (Rachmawati and Samidjan, 2016). Then the shrimp was adapted to the media culture environment and the diet in 7 (seven) days. The weith gain was measured every week for 60 days to determine the effect of phytase enzyme on the growth of $L$. vannamei.

\section{Diet Preparation}

Diet that was used in the study contained $40 \%$ protein and $3600 \mathrm{Kcal} \mathrm{DE} / \mathrm{kg}$ energy according to energy requirements for of $L$. vannamei. (Suprayudi et al., 2012). The ingredients of the diet were fish meal, soybean meal, cornflour, rice bran, wheatflour, fish oil, corn oil, minerals and vitamine mix (aquamine), $\mathrm{CMC}, \mathrm{Cr}_{2} \mathrm{O}_{3}$ as indirect indicataor of diet digestibility as much as $1 \% \quad(N R C, 1993)$ and phytase enzyme. The enzyme used in the study was Natuphos ${ }^{\circledR} 5000$ that was produced by PT.BASF Indonesia. Proxymate analysis, based on (AOAC, 1990), was used to identify nutrient contents. The diet composition and the results of proxymate analysis were shown in the Table 1.

Table 1. The Diet Composition for White Shrimp (L. vannamel)

\begin{tabular}{|c|c|c|c|c|}
\hline \multirow{2}{*}{ Ingredients } & \multicolumn{4}{|c|}{ Treatment } \\
\hline & A & $\mathrm{B}$ & $\mathrm{C}$ & $\mathrm{D}$ \\
\hline Phytase Enzyme (g) & 0 & 0.1 & 0.2 & 0.3 \\
\hline Fish Meal & 28 & 28 & 28 & 27.9 \\
\hline $\begin{array}{l}\text { Soybean Meal } \\
\text { Cornflour }\end{array}$ & $\begin{array}{l}37.8 \\
6.5\end{array}$ & $\begin{array}{l}37.8 \\
6.5\end{array}$ & $\begin{array}{l}37.8 \\
6.5\end{array}$ & $\begin{array}{l}37.8 \\
6.5\end{array}$ \\
\hline Rice Bran & 7.9 & 7.9 & 7.9 & 7.9 \\
\hline Wheatflour & 11.8 & 11.7 & 11.6 & 11.5 \\
\hline Fish Oil & 3 & 3 & 3 & 3 \\
\hline Corn Oil & 2 & 2 & 2 & 1.99 \\
\hline Vit Min Mix & 1 & 1 & 1 & 1 \\
\hline CMC & 1 & 1 & 1 & 1 \\
\hline $\mathrm{Cr}_{2} \mathrm{O}_{3}$ & 1 & 1 & 1 & 1 \\
\hline Total & 100 & 100 & 100 & 100 \\
\hline \multicolumn{5}{|l|}{ The Results of Proxymate Analysis } \\
\hline Protein $(\%)^{*}$ & 40.25 & 40.28 & 40.32 & 40.26 \\
\hline Fat $(\%)^{*}$ & 9.47 & 9.58 & 9.75 & 9.63 \\
\hline $\operatorname{BETN}(\%)^{*}$ & 40.12 & 40.12 & 40.18 & 40.21 \\
\hline Energy (Kcal)* & 306.42 & 306.27 & 306.32 & 306.19 \\
\hline Ratio E/P & 9.12 & 9.23 & 9.18 & 9.23 \\
\hline
\end{tabular}

Based on Wilson (1987) : Digestible Energy for $1 \mathrm{~g}$ protein equals $3.5 \mathrm{kcal} / \mathrm{g}, 1 \mathrm{~g}$ fat equals $8.1 \mathrm{kcal} / \mathrm{g}$, and $1 \mathrm{~g}$ carbohydrate equals $2.5 \mathrm{kcal} / \mathrm{g}$

Based De Silva (1987) : value of $\mathrm{E} / \mathrm{D}$ for optimum growth is $8-12 \mathrm{Kcal} / \mathrm{g}$

* Laboratory for Animal Nutrient, Faculty of Animal Husbandry and Agriculture, Diponegoro University (2017) 
Research method used experiment with Completely Randomized Design, 4 (four) treatments and 4 (four) repetitions. The treatments in this study were different doses of phytase enzymes, namely A (0 U/kg diet), B (500 U/kg diet), C (1000 U/kg diet), and D (1500 U/kg diet). The levels of dose of phytase enzyme suplementation based on Suprayudi et al. (2012) and Rachmawati and Samidjan (2016) study, but they were modified. The shrimp was fed 4 (four) times daily with the diet dose of $5 \%$ of the weight.

\section{Preparation for Intensive Culture System}

The study was conducted in Kendal District, Central Java, Indonesia. The study utilized media culture with the total area of $6000 \mathrm{~m}^{2}$ devided into 12 ponds, each has area of $500 \mathrm{~m}^{2}$. The bottom of the pond was covered by plastict mulse. Then the pond was filled with the saline water the depth of $1.5 \mathrm{~m}$, obtained from reservoir pond with. Each pond was installed 4 (four) paddle wheels. One week after the pond filled with saline water, white shrimp juveniles were spread in each pond with the density of $80 \mathrm{shrimp} / \mathrm{m}^{2}$.

\section{Water Quality Observation}

Parameters included $A D C_{F}, A D C_{P}, E F U$, PER, FCR, RGR, SR, and water quality. Fenucci (1981) method was used to measure $A D C_{F}$ and $A D C_{P}$. Tacon (1987) method was used to measure EFU, PER, and FCR. NRC,
(1993) method was used to measure RGR and SR.

\section{Observed Parameters}

Physical and chemical water quality parameters consisted temperature measured by HANNA: HI. 8633, pH measured by Jenway 3510 , dissolved oxygen measured by Jenway 970 and ammoniac measured by (APHA, 2005). Water salinity was measured everyday and calcualted by (ATAGO S-10, Japan).

\section{Data Analysis}

Data Analysis used analysis covariance (ANOVA). If the result had significant effect $(P<0.05)$ or high significant effect $(P<0.01)$, the next step was analized using Duncan test to find mean value of the treatment. No needs to write Polynomial orthogonal was used to find optimum dose (Steel et al., 1993). Water quality was descriptively explained.

\section{Results and Discussion}

Result

The suplementation of phytase enzyme in the diet had very significant effect $(P<0.01)$ on $A D C_{F}, A D C_{P}, E F U, P E R, F C R, R G R$; however, it had insigfincant effect on SR $L$. vannamei were shown in the Table 2.

Table 2. Phosphore Digestibility $\left(A D C_{F}\right)$. Protein Digestility $\left(A D C_{P}\right)$, Efficiency Of Diet Utilizatio (EFU), Protein Efficiency Ratio (PER), Diet Conversion Ratio (FCR), And Relative Growth Rate (RGR) and Survival Rate (SR) of L.vannamei

\begin{tabular}{lcccc}
\hline \multirow{2}{*}{ Data } & \multicolumn{4}{c}{ Treatments } \\
\cline { 2 - 5 } & $\mathrm{A}$ & $\mathrm{B}$ & $\mathrm{C}$ & $\mathrm{D}$ \\
\hline ADC $_{\mathrm{F}}(\%)$ & $58.03 \pm 0.21^{\mathrm{d}}$ & $67.98 \pm 0.23^{\mathrm{c}}$ & $79.98 \pm 0.37^{\mathrm{a}}$ & $71.60 \pm 0.32^{\mathrm{b}}$ \\
ADC $_{\mathrm{P}}(\%)$ & $60.43 \pm 1.78^{\mathrm{d}}$ & $70.98 \pm 2.24^{\mathrm{c}}$ & $88.65 \pm 1.89^{\mathrm{a}}$ & $73.29 \pm 2.15^{\mathrm{b}}$ \\
EFU (\%) & $53.50 \pm 0.23^{\mathrm{d}}$ & $62.54 \pm 2.19^{\mathrm{c}}$ & $79.98 \pm 2.21^{\mathrm{a}}$ & $67.75 \pm 2.20^{\mathrm{b}}$ \\
PER & $1.82 \pm 0.21^{\mathrm{a}}$ & $2.02 \pm 0.23^{\mathrm{c}}$ & $3.25 \pm 0.20^{\mathrm{a}}$ & $2.45 \pm 0.23^{\mathrm{b}}$ \\
FCR & $2.64 \pm 0.15^{\mathrm{c}}$ & $2.34 \pm 0.23^{\mathrm{b}}$ & $1.78 \pm 0.08^{\mathrm{a}}$ & $2.02 \pm 0.12^{\mathrm{b}}$ \\
RGR (\%) & $1.89 \pm 0.01^{\mathrm{d}}$ & $2.65 \pm 0.06^{\mathrm{c}}$ & $3.05 \pm 0.03^{\mathrm{a}}$ & $2.80 \pm 0.08^{\mathrm{b}}$ \\
SR (\%) & $96.33 \pm 3.32^{\mathrm{a}}$ & $90.00 \pm 2.53^{\mathrm{a}}$ & $93.33 \pm 2.32^{\mathrm{a}}$ & $90.00 \pm 2.35^{\mathrm{a}}$ \\
Phytic Acid of Diet (\%) & 0.73 & 0.68 & 0.58 & 0.63 \\
Phytic Acid of Feces (\%) & 0.64 & 0.57 & 0.29 & 0.46 \\
Phytitc Acid Decrease (\%) & 0.09 & 0.11 & 0.29 & 0.17 \\
\hline
\end{tabular}

Note: The Values with the same superscripts in the column show insignificant 
Table 3. Water Quality Parameters

\begin{tabular}{|c|c|c|c|c|c|}
\hline \multirow{2}{*}{ Parameter } & \multicolumn{4}{|c|}{ Value Ranges } & \multirow{2}{*}{ References } \\
\hline & $A$ & $\mathrm{~B}$ & $\mathrm{C}$ & $\mathrm{D}$ & \\
\hline Temperature $\left({ }^{\circ} \mathrm{C}\right)$ & $28-30$ & $28-30.5$ & $28-30$ & $28.5-30.5$ & $27.5-31.5^{a}$ \\
\hline DO (mg/l) & $3-4$ & $3.5-4.5$ & $3.5-4.2$ & $3.5-4.5$ & $3.2-4.2^{\mathrm{a}}$ \\
\hline Salinity (ppt) & $29-34$ & $30-35$ & $28-33$ & $29-35$ & $4-35^{a}$ \\
\hline $\mathrm{pH}$ & $7.5-8.5$ & $7.7-8.2$ & $7.5-8.2$ & 7.7-8.5 & $7.6-8.6^{a}$ \\
\hline Ammoniac (ppm) & $0.01-0.23$ & $0.01-0.38$ & $0.01-0.22$ & $0.01-0.31$ & $<1^{a}$ \\
\hline
\end{tabular}

${ }^{a}$ Soundarapandian et al. (2010)

Table 3. show that in the temperature between $28{ }^{\circ} \mathrm{C}$ and $30.5 \stackrel{\circ}{\circ}$, DO, salinity, $\mathrm{pH}$, ammoniac were 3-4.5 mg/l, 28-35 ppt, 7.5-8.5 and $0.01-0.013 \mathrm{ppm}$ respectively. The water quality was suitable for white shrimp culture (Soundarapandian et al., 2010).

\section{Discussion}

The results showed that a dose of 500 $1500 \mathrm{U} / \mathrm{kg}$ of diet could increase phosphore digesibility (ADCF), as shown in Table 2. This increase was due to an increase in phytic acid hydroxicity caused by phytase enzyme supplementation. The results of this study are in accordance with Baruah et al. (2007) and Ravindran (2005) which states that phytase enzymes can hydrolyze phytic acid into inositol and phosphate acids so can increase phosphorus absorption.
The dose of $1000 \mathrm{U} / \mathrm{kg}$ diet (treatment C) phytase enzyme gave the highest phosphore digestibility. The same result was also reported by Storebakken et al. (1998) that teh dose of $1000 \mathrm{U} / \mathrm{kg}$ diet phytase enzyme was able to improve the phosphore digestibility of rainbow trout (O. myskiss). Rachmawati and Samidjan (2016) and Rachmawati et al. (2018) also reported the same results on Penaeus monodon and Chanos chanos studies.

The relationship of phytase enzyme suplementation and $A D C_{F}$ based on Polynomial Orthogonal test has a quadratic relationship. The equation was $Y=-0.00003 x^{2}+0.046 x+$ 57.271 and $R^{2}=0.95$, from this equation can be found the optimum dose of phytase enzyme on $A_{D C}$ and $R^{2}=0.95$ states that $95 \% A C_{F}$ is influenced by the suplementation of phytase enzymes in diet while environmental factors only affect $5 \%$ (Fig 1). The optimum dose of the study on $A D C_{F}$ was $867 \mathrm{U} / \mathrm{kg}$ diet with the value of $74.09 \%$.

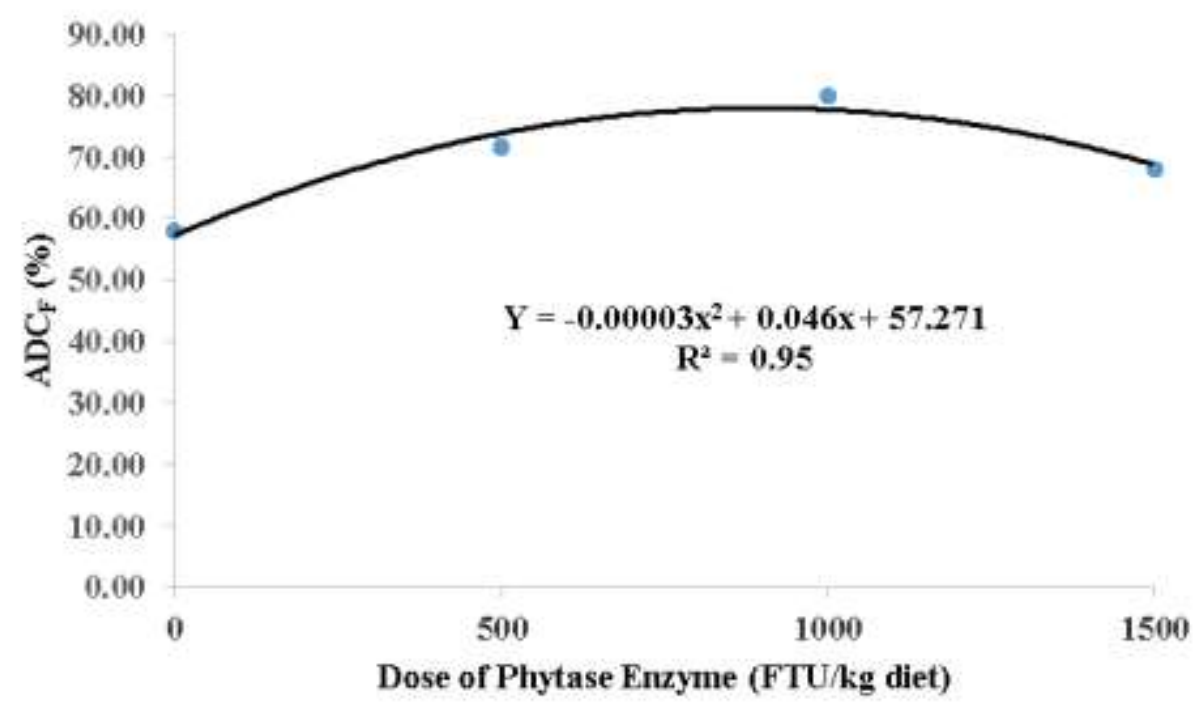

Figure. 1. Relationship Graph between phytase enzyme and $A D C_{F}$ of $L$. vannamei 
The suplementation of phytase enzyme with the doses of 500-1500 U/kg diet has higher increase of $A D C_{P}$ than those of $0 \mathrm{U} / \mathrm{kg}$ diet dose (Table 2). It was suggested that phitic acid has ben unbinded by the phytase enzyme; therefore, protein can be readily digested. Similar result was reported by Carter and Sajjadi (2011) that the suplementation of phytase enzyme in the diet can have Atlantic salmon (Salmo solar) increased in the protein absorption. Phytase enzyme suplementation in the diet can break down phytine-protein compund (Baruah et al., 2007). Similar results have been obtained from the studies on Labeo rohita (Baruah et al., 2007), Channos channos (Hassan et al., 2009; Rachmawati et al., 2017), Penaeus monodon (Rachmawati and Samidjan, 2016), Tilapia Saline (Rachmawati et al., 2018) and Cyprinus carpio (Rachmawati and Samidjan, 2016).

This study show that the phytase enzyme suplementation in the plant based diet can increase the digestibility of phosphore and protein. The result was also supported by the study (Phromkunthong et al., 2010). They found that the phytase enzyme suplementation can increase the digestibility of plant based diet as protein source. Phytase enzyme can break down anti-nutrient in the diet to incrase diet digestibility and diet nutrients (Cao et al., 2007).

The relationship of phytase enzyme suplementation and $\mathrm{ADC}_{\mathrm{p}}$ based on Polynomial Orthogonal test has a quadratic relationship. The equation was Polynomial orthogonal test show that the relationship between phytase enzyme and $A D C_{P}$ was in quadratic form. The equation was as follow : $Y=-0.00003 x^{2}+$ $0.0552 x+58.654$ and $R^{2}=0.84$, from this equation can be found the optimum dose of phytase enzyme on $A D C_{p}$ and $R^{2}=0.84$ states that $84 \% A_{P D C}$ is influenced by the suplementation of phytase enzymes in diet while environmental factors only affect $16 \%$ (Fig 2). The optimum dose for $A D C_{P}$ was 920 $\mathrm{U} / \mathrm{kg}$ diet with the value of $80.00 \% \mathrm{ADC}_{\mathrm{P}}$.

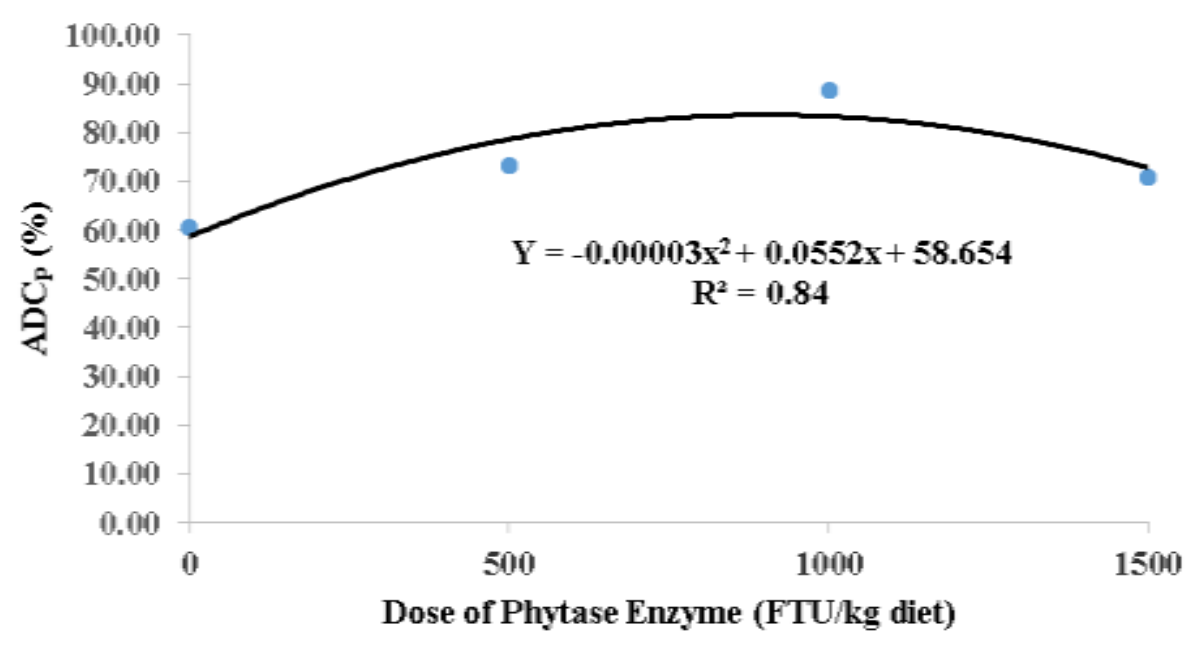

Figure. 2. The relationship between phytase enzyme and $A D C_{p}$ of $L$. vannamei

The result of various doses of phytase enzyme on diet utilization was highly significant $(P<0.001)$. Suplementation of phytase enzyme was able to improve efficiency of diet utilization in white shrimp. Wang et al., (2009) finding supported the result that phytase enzyme can increase efficiency of diet utilization in the digestible system.

Table 2, show that the highest efficiency of diet utilization (EFU) was treatment C (1000 $\mathrm{U} / \mathrm{kg}$ diet phytase enzyme suplementation) with the value of $79.98 \%$ EFU, while the lowest value was obtained from the treatment $A$ ( 0 $\mathrm{U} / \mathrm{kg}$ diet phytase enzyme suplementation) with the value of $53.50 \%$ of EFU. The dose of 1000
$\mathrm{U} / \mathrm{kg}$ diet phytase enzyme suplementation was suggested that the dose was just the right dose to hydrolize phytic acid into readily availablenutrient to absorb. The finding was supported by Chung (2001) study that he suggested the phytase acid can increase efficiency of diet utilization. Meanwhile, the lowest EFU was due to shrimp cannot utilize the ntrient since it has still bound by phytic acid. The similar result was also found by Rachmawati et al. (2017), Rachmawati et al. (2018), Rachmawati and Samidjan (2018) and Qinghui, and Xie (2005)..

The relationship of phytase enzyme suplementation and EFU based on Polynomial 
Orthogonal test has a quadratic relationship. The equation was Polynomial orthogonal test on the relationship between the suplementation of phytase enzyme and EFU resulted in quadratic equation as follow: $Y=-0.00003 x^{2}+0.0554 x+$ 52.118 and $R^{2}=0.89$, from this equation can be found the optimum dose of phytase enzyme on
EFU and $R^{2}=0.89$ states that $89 \%$ EFU is influenced by the suplementation of phytase enzymes in diet while environmental factors only affect $11 \%$ (Fig 3). The optimum dose of phytase enyme suplementation was $923 \mathrm{U} / \mathrm{kg}$ diet with the value of $77.69 \%$ EFU.

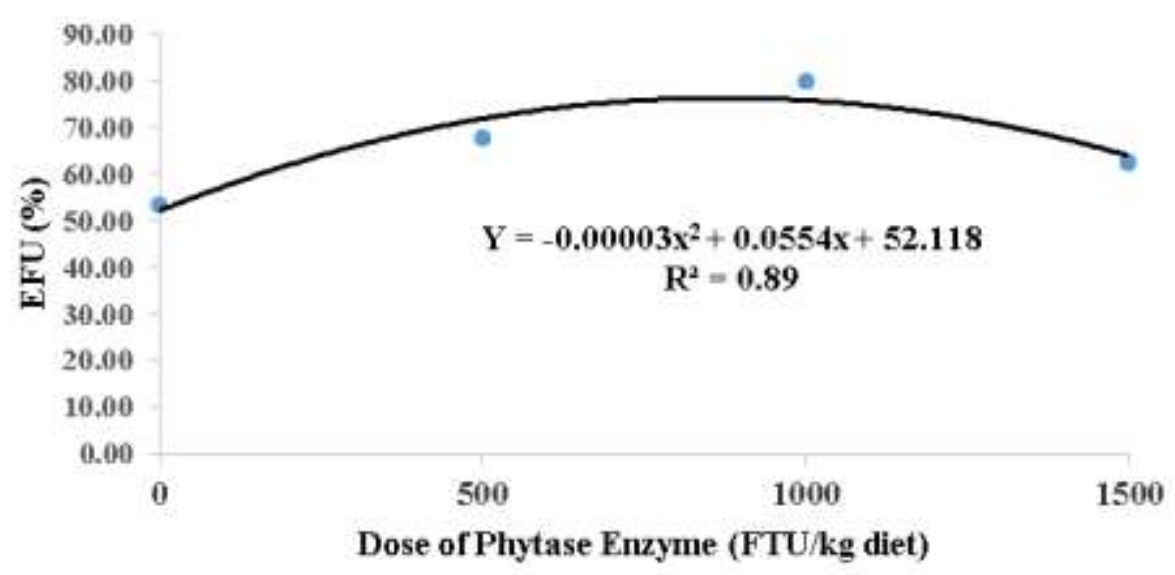

Figure. 3. The relationship Graph between phytase enzyme and EFU of $L$. vannamei

Treatment C (1000 U/kg diet phytase enzyme suplementation) gave highest PER with the value of 3.25 , while the lowest protein efficiency ratio was obtained from Treatment $A$ ( $0 \mathrm{U} / \mathrm{kg}$ diet phytase enzyme suplementation) with the value of 1.82 . The highest value of protein efficiency was suggested because of the result of effective dose to break down the binding of phytic acid with protein and minerals compund; therefore, it made digesting enzymes readily available. Tawwab (2012) aslo reported that hydrolysis of phytic acid due to phytase enzyme can increase protein absorption. The increase of protein efficiency due to the suplementation of phytase enzyme in the diet was also reported by Vielma et al. (2004) and Suguira et al. (2001).

The relationship of the suplementation of phytase enzyme and protein efficiency ratio was indicated by quatratic equation as follows: $\mathrm{Y}=-0.000002 \mathrm{x}^{2}+0.0031 \mathrm{x}+1.71$ and $\mathrm{R}^{2}=$ 0.80 , from this equation can be found the optimum dose of phytase enzyme on PER and $R^{2}=0.80$ states that $80 \%$ PER is influenced by the suplementation of phytase enzymes in diet while environmental factors only affect 20 $\%$ (Fig 4). The optimum dose of phytase enzyme suplementation was $915 \mathrm{U} / \mathrm{kg}$ diet with the value of 3.02 PER.

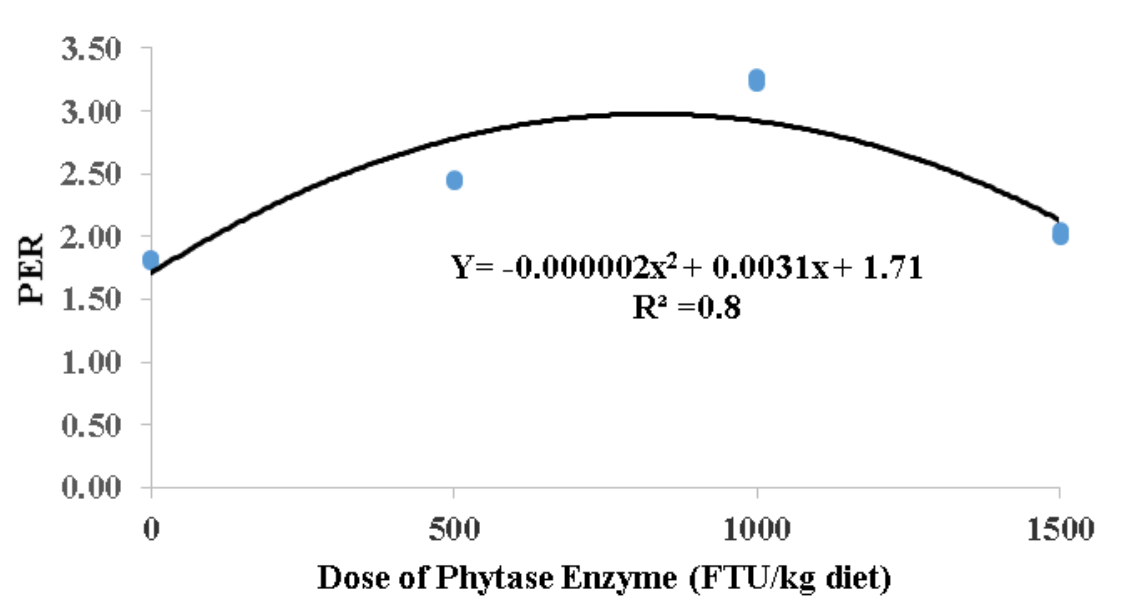

Figure 4. The relationship Graph between phytase enzyme and PER of $L$. vannamei 
The doses of phytase enzyme of 500 $\mathrm{U} / \mathrm{kg}$ diet, $1000 \mathrm{U} / \mathrm{kg}$ diet and $1500 \mathrm{U} / \mathrm{kg}$ diet (Treatments $B, C$ and $D$ ) gave lower FCR than that of $0 \mathrm{U} / \mathrm{kg}$ diet dose (Treatment A). They were suggested that the phytase enzyme can catlyze the break down of phytic acid; therefore, it unbound the compound of phytic acid and protein and minerals into trypsine enzyme which can break down protein into amino acids. In turn, it increased efficiency of diet utilization and lowered diet conversion. Tahoun et al. (2009) stated that the lower the efficiency of diet conversion the better diet utilization. Other studies which had similar results were done in Rainbow trout (Wang et al., 2009) and Labeo Rohita (Baruah et al., 2007).

The lowest ratio of FCR was obtained from Treatment $C(1000 \mathrm{U} / \mathrm{kg}$ diet) with the value of 1.78 , followed by treatments $D, B$, and A with the values pf 2.02, 2.34, and 2.64 respectively. The dose of $1000 \mathrm{U} / \mathrm{kg}$ diet phytsae enzyme was suggested the right dose of enzyme to increase efficiency of diet utilization. Rachmawati and Samidjan (2016), Rachmawati et al. (2017), Rachmawati et al. (2018), and Rachmawati and Samidjan (2018) found the same result in his study that phytase enzyme has an important role in increasing efficiency of diet utilization and can make diet coonversion ratio lower than that of without phytase enzyme.

The relationship between between the suplementation of phytase enzyme and protein efficiency ratio was indicated by quatratic equation as follows : $Y=0.000001 x^{2}+0.002 x$ +2.6655 and $R^{2}=0.97$, from this equation can be found the optimum dose of phytase enzyme on FCR and $\mathrm{R}^{2}=0.97$ states that $97 \%$ FCR is influenced by the suplementation of phytase enzymes in diet while environmental factors only affect $3 \%$ (Fig 5). The optimum dose of phytase enzmye for FCR was $1000 \mathrm{U} / \mathrm{kg}$ diet with the value of 1.78 .

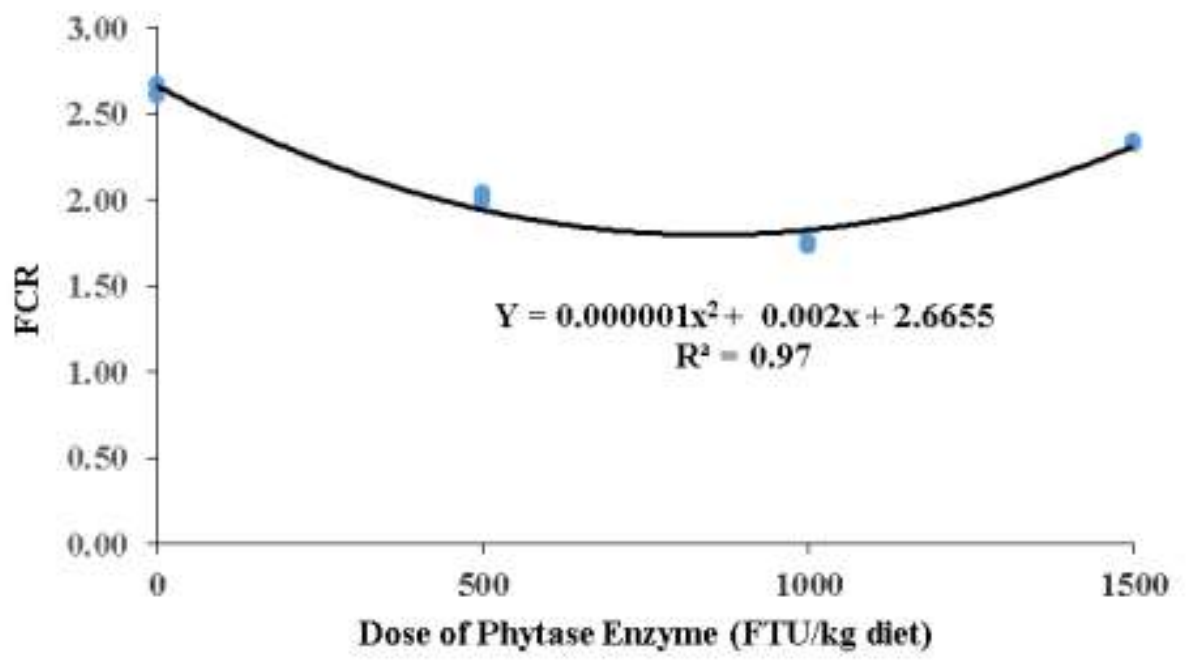

Figure 5. The relationship Graph between phytase enzyme and FCR of $L$. vannamei

The results show that the phytase enzyme suplementation in the diet significantly $(P<0,01)$ influenced the growth of white shrimp. It can be proven by comparing the content of phytic acid in the diet and feces. The contents of phytic acid in the feces were lower than those in the diet by as much $0.09 \%, 0.11 \%, 0.30 \%$, $0.17 \%$ as in the treatments of $A, B, C$, and $D$ respectively, as shown in the Table 2 . The results of the laboratory test on phytic acid content in Treatment A (0 U/kg diet), B (500 $\mathrm{U} / \mathrm{kg}$ diet), C (1000 U/kg diet), D (1500 U/kg diet) were $0.73 \%, 0.68 \%, 0.58 \%$, and $0.63 \%$ respectively; while the contents of phytic acid in the feces were $0.64 \%, 0.57 \%, 0.29 \%$, and $0.46 \%$ for treatments $A, B, C$, and $D$.
Those data show that diet containing phytic acid can influence the growth of white shrimp. This instance was supported by NRC (1993), it reported that diet containing 0,5\% phytic acid can reduce growth and diet efficiency in rainbow trout (O. mysskis). The suplementation of phytase enzyme can unbind protein from phytic acid that increase the growth of fish (Amoah et al., 2011; Haghbayan, and Mehrgan, 2015). Similar results were also reported in Oreochromis niloticus (Tahoun et al., 2009), Epinephelus fuscoguttatus (Shapawi et al., (2013), Marsupenaeus japonicus (Bulbul et al., 2015), Psetta maxima L. (Danswitz et al., 2016), Penaeus monodon (Rachmawati and Samidjan,(2016), Chanos chanos (Rachmawati et al., 2017), Tilapia saline (Rachmawati et al., 
2018) and Cyprinus carpio (Rachmawati and Samidjan, 2018).

The highest relative growth rate (RGR) of white shrimp happened in the Treatment $\mathrm{C}$ $(1000 \mathrm{U} / \mathrm{kg}$ diet phytase enzyme suplementation) with the value of $3.05 \%$, followed by Treatments $\mathrm{D}, \mathrm{B}$, and $\mathrm{A}$ with the value of $2.80 \%, 2.65 \%$, and $1.89 \%$ respectively. The dose of $(1000 \mathrm{U} / \mathrm{kg}$ diet phytase enzyme suplementation was suggested the right dose to reduce phytic acid in the food. It was shown in the Table 2. the dose gave the biggest decrease in phytic acid as much as $0.29 \%$, compared to other treatments. The similar result of study on Penaeus monodon was discovered by Rachmawati and Samidjan (2016). Moreover, Yu and Wang (2000) found that the dose of $1000 \mathrm{U} / \mathrm{kg}$ diet phytase enzyme suplementation can increase weight by $25 \%$ in crucian carp Carassius carassius, as Rachmawati et al. (2017), Rachmawati et al. (2018), Rachmawati dan Samidjan (2018) and Hassan et al. (2009) did in Chanos chanos.

The lowest RGR of white shrimp was found in the treatment $A(0 \mathrm{U} / \mathrm{kg}$ diet) with the value of $1.89 \%$. This was because of lack of phytase enzyme; therefore, the nutrients were not readily able to absorb. In turn, the Treatment $A$ had the lowest decrease of phytic acid content as much as $0.09 \%$. The lack of enzyme caused phytic acid not able to break down into inositol and phosphate acid and would deprive white shrimp from inositol to grow. The effect of inositol deficiency in the fish was report by (NRC, 1993). It said that inositol deficiency can reduce appetite, slow bowel movement, cause anemia, and slow growth. The inositol deficiency also hampered mineral compound break down so it made shortage of phosphor availability. Phosphor is an important element to transform energy (NRC, 1993). The similar results were reported by Shapawi et al. (2013), Rachmawati and Samidjan (2016), Rachmawati et al. (2017), Rachmawati et al. (2018), Rachmawati and Samidjan (2018).

The relationship of phytase enzyme and RGR polynomial orthogonal resulted in quadratic pattern as follows $Y=-0.000001 x^{2}+$ $0.0025 x+1.8905$ and $R^{2}=0.99$, from this equation can be found the optimum dose of phytase enzyme on $R G R$ and $R^{2}=0.99$ states that $99 \%$ RGR is influenced by the suplementation of phytase enzymes in diet while environmental factors only affect $1 \%$ (Fig 6). The optimum dose of phytase enzyme on RGR was $1000 \mathrm{U} / \mathrm{kg}$ diet with the value of $3.05 \%$.

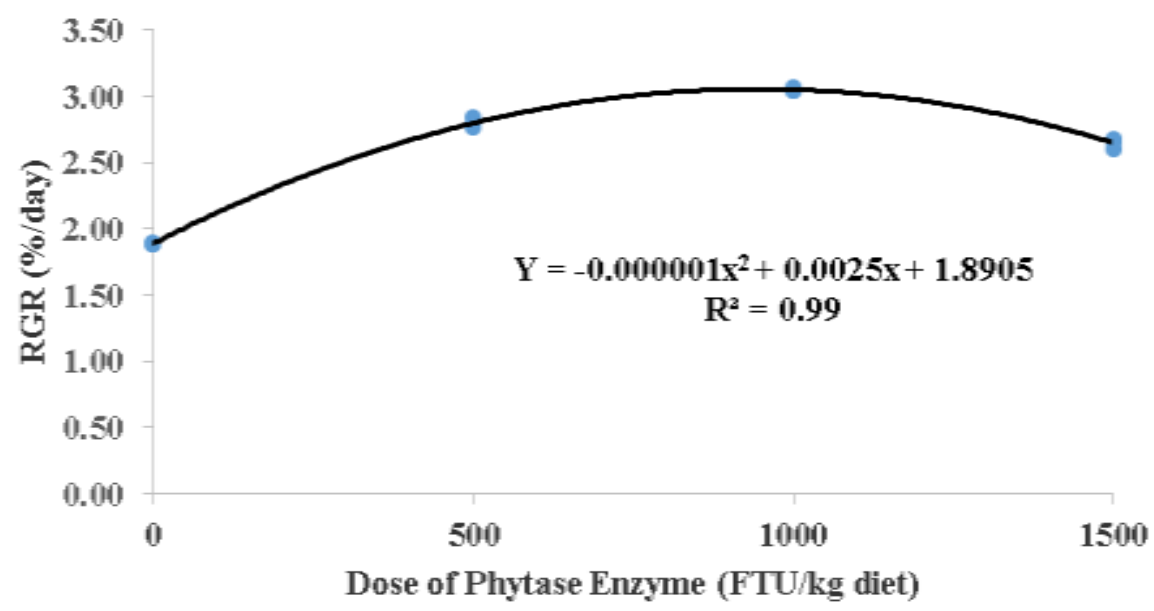

Figure 6. Relationship Graph between phytase enzyme and RGR of $L$. vannamei

The supplementation of phytase enzyme in the diet was insignifant $(P>0.05)$ on the survival rate of white shrimp, althought it had significant effect on diet digestibility, efficiency of diet utilization, and growth. This phenomenon was also reported by Yakuputiyage (2013). Moreover, Yakuputiyage (2013) suggested that survival rate was influenced by initial treatment and quality of culture media. The similar results were reported by Yoo et al. (2005), Debnath (2005), Baruah et al. (2007), Tahoun et al. (2009), Hassan et al. (2009), Bulbul et al. (2015), Danwitz et al. (2016), Husain et al. (2014), Rachmawati and Samidjan, (2016), Rachmawati et al. (2017). 


\section{Conclusion}

Conclusions from the results of this study that phytase enzyme supplementation in diets with different doses can increase the growth of $L$. vannamei in in the intensive system aquaculture The best treatment result was the suplementation of $1000 \mathrm{U} / \mathrm{kg}$ diet phytase enzyme in the diet. The optimum doses of phytase enzyme in the diet of $1000 \mathrm{U} /$ $\mathrm{kg}$ of diet produces $L$. vannamei growth up to $3.05 \%$ / day.

\section{Acknowledgement}

The authors thankfully acknowledge for Mr. Imam Suherman chairman of Shrimp farmers association in District of Kendal, Central Java, Indonesia who has lent his ponds to research and also Dean of Research Institute and Community Service, Diponegoro University who has provided research

\section{References}

Amoah, Y. T., H. Thorarensen., O. Sigurgeirrson. 2011. Effect of dietary protein levels on growth and protein utilization In Juvenile Arctic Char (Salvelinus alpinus). Fisheries Training Programme, United Nations University, $26 \mathrm{pp}$.

AOAC, 1990. Official Methods of Analysis. Association of Official Analytical Chemists. Fifteenth edition, Washington D.C. 1298 pp.

APHA. 2005. Standard methods for examination of water and wastewater. 21st Edn. Washington DC, USA.

Baruah, K., N. P. Sahu, A. K. Pal, D. Debnath., S. C. Mukherjee. 2007. Dietary Microbial Phytase and Citric Acid Synergistically Enhances Nutrient Digestibility and Growth Performance of Labeo rohita (Hamilton) Juveniles At SubOptimal Protein Level. Aquaculture Research, 38(2):109-120.

Bulbul, M., Md. A. Kader, M. A. Ambak, Md. S. Hossain, M. Ishikawa., S. Koshio. 2015. Effects of Crystalline Amino Acids, Phytase and fish soluble supplements in improving nutritive values of high plant protein based diets for Kuruma Shrimp,
Marsupenaeus japonicus. Aquaculture Elsevier, 438:98-104.

Cao, L., W. Wang, C. Yang,Y. Yang, J. Diana, A. Yakupitiyage, Z. Luo., D. Li. 2007. Application of microbial phytase in fish diet. Enzym and Microbial Technology, 40:497-507.

Chung, T.K. 2001. Sustaining livestock production and environment. Food and Agriculture Asia Pacific Development. Singapore. Pp: 52-54.

Carter, C. G., Sajjadi M. 2011. Low fishmeal diets for Atlantic Salmon, Salmo salar L using soy protein concentrate treated with graded levels of phytase. Aquacult Int 19:431-444.

Danwitz, A. Von, C. G. J. van Bussel, S. F. Klatt., C. Schulz. 2016. Dietary Phytase Supplementation in Rapeseed Protein based Diets Influences Growth Performance, Digestibility and Nutrient Utilisation in Turbot (Psetta maxima L.). Aquaculture, 450:405-411.

Debnath D., Pal A.K., Sahu N.P. 2005. Effect of dietary microbial phytase supplementation on growth and nutrient digestibility of Pangasius pangasius (Hamilton) fingerlings. Aquacult Res, 36(2):180-7.

De Silva, S.S. 1987. Finfish nutrition research in Asia. Proceeding of The Second Asian Fish Nutrition Network Meeting. Heinemann. Singapore. 128 p.

Fenucci, J.L. 1981. Studies on the nutrition of marine shrimp of the Penaeus. Ph.D. Thesis. Faculty of Department of Biology, University of Houston, Houston, Texas, USA.

Haghbayan, S., M. S. Mehrgan. 2015. The Effect of replacing fish meal in the diet with enzyme-treated soybean meal (HP310) on growth and body Composition of Rainbow Trout Fry. Journal of Molecules. Department of Fisheries Science, Science and Study Branch, Islamic Azad University, 20:258266.

Hassan, S., K. Altaff., T. Satyanarayana. 2009. Use of Soybean Supplemented with Cell Bound Phytase for Replacement of Fish Meal in the Diet of Juvenile Milkfish, 
Chanos chanos. Pakistan Journal of Nutrition, 8(4):341-344.

Husain, S.M., T. Hameed, M. Afzal, M.S. Mubarik, M. Asrar, S.Z.H. Shah, S. Ahmad, M.Z.H. Arzalan, D. Riaz, N. Tahir, F. Amber, M.M. Shahzad., Tanwir Ahmad Abbas Khichi. 2014. Effects of phytase supplementation on mineral digestibility in Cirrhinus mrigala fingerlings fed on sunflower meal-based diets. International Journal of Biosciences, 5 ( 12) : 173-181.

Jagannathan, K.R., P.H. Nielsen. 2013. Environmental Assessment of Enzyme Use in Industrial Production - A Literature Review. Journal of Cleaner Production, 42 : 228-240.

Kumar, V., A. K. Sinha, H. P. S. Makkar, G. De Boeck., K. Becker. 2011. Phytate and Phytase in Fish Nutrition. Journal of Animal Physiology and Animal Nutrition, 96 (2012) :335-364.

[NRC] National Research Council. 1993. Nutrient requirement of fish. Washington DC, USA: National Academy Press. Pp 39-53.

Office of Fishery and Maritime District of Kendal, Kendal in number 2017 (Ministry of Marine and Fisheries Central Java, Indonesia, 2018).

Phromkunthong, W., N. Nuntapong., J. Gabaudan. 2010. Interaction of Phytase RONOZYME $\circledast \mathrm{P}(\mathrm{L})$ and Citric Acid on The Utilization of Phosphorus by Common Carp (Cyprinus carpio). Songklanakarin J. Sci. Technol, 32 (6): 547-554.

Rachmawati, D., Istiyanto, Samidjan. 2016. Effect of Phytase Enzyme on Growth Boost in the Artificial Feed Made of Plant Protein to Shorten Production Time of Giant Tiger Prawn [Penaeus monodon, (Fabricus 1798)]. Aquatic Procedia, 7: $46-53$.

Rachmawati, D,. Istiyanto, S., Maizirwan Mel. 2017. Effect of Phytase on Growth Performance, Diet UtilizationEfficiency and Nutrient Digestibility in Fingerlings of Chanos chanos (Forsskal 1775). J. Philippine Journal of Science, 146 (3) : 237-245.
Rachmawati, D., Istitanto Samidjan. 2018. Effect of Phytase Enzyme on Growth, Nutrient Digestibility and Survival Rate of Catfish (Pangasius hypothalamus) Fingerlings. Pertanika J. Trop. Agric. Sci. 41 (2): $865-878$.

Ravindran V, Bryden W.L., Kornegay ET. 2005. Phytates: occurrence, bioavailability, and implications in poultry nutrition. Poult Avian Biol Rev, 6:125-43.

Qinghui, Ai., Xiaojun Xie. 2005. Effects of Dietary Soybean Protein Levels on Energy Budget of The Southern Catfish, Silurus Meridionalis. Comparative Biochemistry and Physiology, 14: 461469.

Shapawi, R., Wing-Keong Ng., Saleem Mustafa. 2007. Replacement of fish meal with poultry by-product meal in diets formulated for the humpback grouper, Cromileptes altivelis. Aquaculture 1 : 118-126.

Soundarapandian, P., Ramanan V., Dinakaran G.K. 2010. Effect of probiotics on the growth and survival of Penaeus monodon (Fabricius) Current Research. Journal of Social Sciences, (2): 51-57.

Sugiura SH, Raboy V, Young KA, Dong FM, Hardy RW. 2001. Availability of phosphorus and trace elements in low phytate varieties of barley and corn for rainbow trout Oncorhynchus mykiss. Aquaculture,170:285-96.

Suprayudi, M.A., Dini Harianto., Dedi Jusadi. 2012. Digestibility of Feed and Growth of White Shrimp Litopenaeus vannamei given Feed Containing Different Phytase Enzymes. Journal of Indonesian Aquaculture. 11(2(:103-108.

Steel R.G.D, Torrie J.H, Dickey DA. 1993. Principles and Procedures of Statistics, 3rd Ed. McGraw Hill International Book Company, Inc. New York. USA, 336-352 p.

Storebakken T, Shearer K.D., Roem A.J. 1998. Availability of protein, phosphorus and other elements in fish meal, soy-protein concentrate and phytase treated soyprotein-concentrate-based diets to Atlantic salmon, Salmo salar. J. Aquact, 161: 365-379. 
Tahoun, A. M., Abo-State, H. A., Hamouda, Y. A. 2009. Effect of Adding Commercial Phytase to DDGS Based Diets on The Performance and Diet Utilization of Nile Tilapia (Oreochromis niloticus) Fingerlings. Agriculture and Environment Science, 5(4):550-555.

Tacon, A.G. 1987. The Nutrition and Dieting of Farmed Fish and Shrimp-A Traning Mannual. FAO of The United Nations. Brazil. p. 106-109.

Tawwab, M A. 2012. Effect of Dietary Protein Levels and Rearing Density on Growth Performance and Stress Response of Nile Tilapia, Oreochromis niloticus (L.). International Aquatic Research, 4(3):1-

Vielma J, Ruohonen K, Gabaudan J., Vogel K. 2004. Top-spraying soybean mealbased diets with phytase improves protein and mineral digestibility but not lysine utilization in rainbow trout, Oncorhynchus mykiss (Walbaum). Aquacult Res, 35(10):955-64.

Wang, F., Y.H. Yang, Z.Z. Han, H.W. Dong, C.H. Yang., Z.Y. Zou, 2009. Effects of phytase pretreatment of soybean meal and phytasesprayed in diets on growth, apparent digestibility coefficient and nutrient excretion of rainbow trout (Oncorhynchus mykiss Walbaum). Aqua. Int, 17: 143-157.

Wilson, R.P. 1982. Energy relationships in Catfish diets. In: R.R. Stickney and R.T. Lovell (Eds.). Nutrition and Dieting of Channel Catfish. Southern Cooperative Series. 193-201 p.

Yakuputiyage, A. 2013. On-Farm Dieting and Diet Management Strategies in Tropical Aquaculture. In M.R. Hasan and M.B. New, eds. On-Farm Dieting and Diet Management in Aquaculture. FAO Fisheries and Aquaculture Technical Paper No. 583. Rome, FAO. p.361-376.

Yoo, G.Y., X. Wang, S. Choi, K. Han, J.C. Kang., S.C. Bai. 2005. Dietary microbial phytase increased the phosphorus digestibily in juvenile Korean rockfish Sebates schlegeli fed diets containing soybean meal. Aquacul, 243: 315-322.

Yu, F.N., Wang D.Z. 2000. The effects of supplemental phytase on growth and the utilization of hosphorus by crucian carp
Carassius carassius. J. Fish SciChin,7(2):106-109. 